\title{
KIRJOITUS
}

HEIKKI HIILAMO \& ANNA SOFIA SALONEN

\section{Diakin uusi rehtori haluaa panostaa diakonian tutkimukseen}

Teologian tohtori Elina Juntunen aloitti Diakonia-ammattikorkeakoulun uutena toimitusjohtaja-rehtorina tammikuun 2021 puolivälissä. Diakonian tutkimus -aikakauskirjan toimitus keskusteli hubtikuussa uuden rehtorin kanssa diakonian tutkimuksen alaan kuuluvista kysymyksistä.

\section{Diakonian tutkijasta Diakin johtajaksi}

Elina Juntusen uran alkutaival liittyy vahvasti diakonian tutkimukseen. Viimeisellä luukulla -tutkimushanke vuonna 2006 oli lähtökohta väitöskirjalle, joka käsitteli diakoniatyön taloudellista avustamista. Väitöksen jälkeen Juntunen on tehnyt nuorten hyvinvointia, toimijuutta ja osallisuutta sekä merkityksellisyyttä, spiritualiteettia ja myötätuntoa työelämässä käsittelevää tutkimusta. Nämä teemat ovat tarjonneet tärkeää tutkimuksellista näkökulmaa työelämään ja johtamiseen. Ennen valintaansa Diakin rehtoriksi Juntunen työskenteli asiantuntija- ja johtotehtävissä muun muassa AVA-akatemiassa, Kirkkohallituksessa sekä Diakissa.

Juntusen mukaan ajankohtainen yhteiskunnallinen tilanne kutsuu tutkimaan monia diakonian näkökulmasta keskeisiä teemoja. Näitä ovat erityisesti koronaviruspandemian vaikutukset, yksinäisyyteen liittyvät kysymykset ja pandemian aikana syntyneet uudet auttamisen ja tuen muodot. Lisäksi perheiden tilanne huolettaa Juntusta. Juntunen kertoo vastikään jutelleensa 


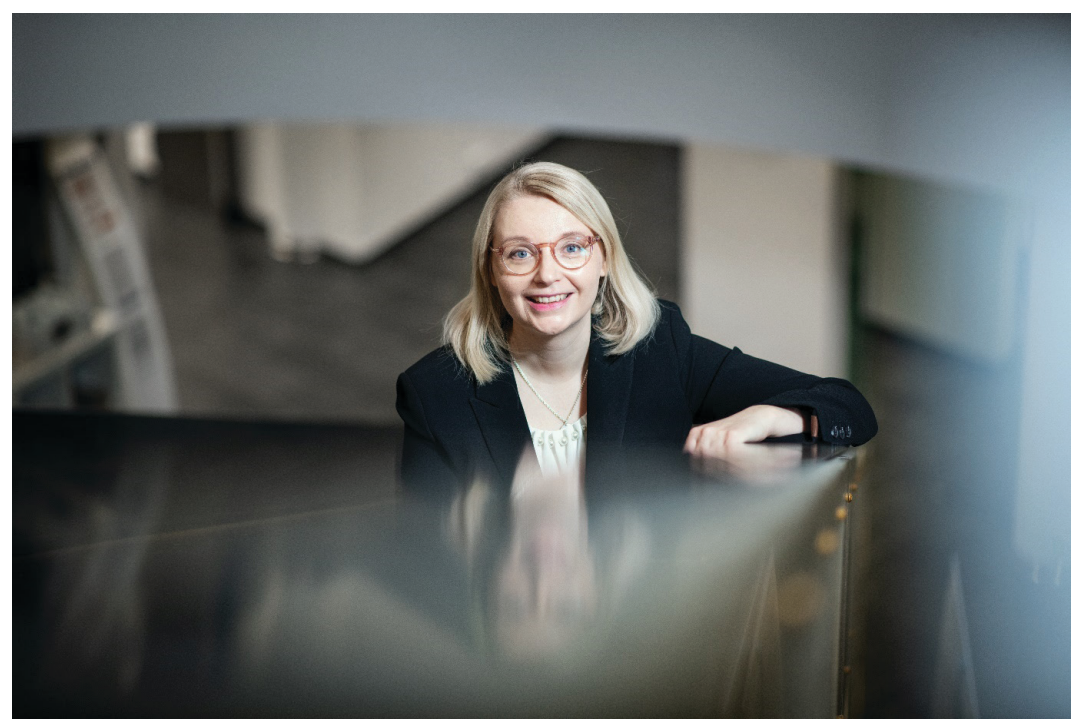

Kuva 1. Diakin uusi rehtori Elina Juntunen. Kuvaaja Meeri Utti.

useammankin sidosryhmän kanssa lasten, nuorten ja perheiden pahoinvoinnin lisääntymisestä viime vuosina. Näiden ongelmien ratkomisen avuksi toivotaan tutkimuksellista näkökulmaa.

Yksi kiinnostava tutkimuksen aihe olisi Juntusen mukaan se, miten diakonia tulisi määritellä nykyajan kontekstissa. Aihe kumpuaa Diakin sisäisistä keskusteluista.”Diakissa olemme miettineet sitä, että meille olisi tärkeää määrittää, mitä me tarkoitamme diakonialla ja mitä diakonia Diakin näkökulmasta tarkoittaa? Tämä on yhteinen, usein esille tuleva keskustelun aihe, mutta meillä on myös sisäisesti tarve pohtia asiaa, ja tässä tutkimuksellinen orientaatio on hyvin tärkeä."

\section{Moniarvoisuutta kristilliseltä arvopohjalta}

Kysyttäessä diakoniakoulutuksen painoarvosta ja merkityksestä Juntunen ottaa esiin Diakin arvot. Hänen mukaansa sana diakonia heijastaa oppilaitoksen nimessä Diakin lähtökohtia ja arvomaailmaa. Arvokysymykset ovat keskeisiä työyhteisölle. "Kun rekrytoimme uusia työntekijöitä, puhumme ennen kaik- 
kea siitä, mihin henkilö on tulossa töihin: että tämä on Diakonia-ammattikorkeakoulu, ja mitä se diakonia tarkoittaa. Arvomaailma siinä on vahvasti mukana."

Juntusen mukaan Diakin erityisluonne tunnustetaan myös laajemmin yhteiskunnassa. "Keskusteluissa koulutuspolitiikan toimijoiden ja ministeriön kanssa tunnustetaan, että meidän erityistehtävä on kirkon alan kouluttajana toimiminen. Vaikuttaa siltä, että olemme saaneet siihen tuen ja tunnustuksen. Ja luotan että saadaan tulevaisuudessa myöskin. Diakin erityisprofiili on siinä, että hoidamme nimenomaan tämän alueen koulutusta ja tutkimus- ja kehitystyötä.”

Juntunen ei epäröi kysyttäessä, voiko Diakia hänen mielestään luonnehtia kristillistaustaiseksi oppilaitokseksi. ”Voi. Kyllä se meidän perustana on. Se on sanoitettuna meidän arvoissakin, kristillisyyteen pohjautuva lähimmäisenrakkaus.” Käytännössä kristillinen tausta näkyy Juntusen mukaan ensinnäkin ihmiskäsityksessä, joka tunnustaa ja ottaa huomioon ihmisen spirituaalisen ulottuvuuden.

Ihmisarvon puolustamisen lisäksi kristillisyys näyttäytyy yhteiskunnallisena toimintana: "Sitä on yhteiskunnallinen vaikuttaminen, rakenteisiin vaikuttaminen ja epäkohtiin kantaa ottaminen. Ajattelen, että tämäkin nousee kristillisistä ja diakonian lähtökohdista." Juntunen pohtii, onko tälle ulottuvuudelle tarvetta erityisesti tässä ajassa:"Ollaanko sellaisessa tilanteessa, jossa pitäisi entisestään korostaa tätä puolta. Nimenomaan rakenteisiin vaikuttamista, yhteiskunnallista vaikuttamista."

Toisinaan Diakin kristillinen arvopohja voi Juntusen mukaan herättää kysymyksiä."Joissain arjen tilanteissa esimerkiksi opiskelijaksi hakevat saattavat kysyä sitä, että mikä on Diakin arvoperusta ja mitä se tarkoittaa suhteessa uskontoon ja uskontoihin. Joillekin se saattaa olla kynnys hakea Diakiin.” Juntunen yhdistää Diakin kristillisen taustan kuitenkin ennen kaikkea moniarvoisuuteen: "Meille on tosi tärkeää moninaisuuden ja moniarvoisuuden teemat, mutta myös nämä nousevat avoimesta kristillisyydestä ja lähimmäisyydestä."

\section{Diak ja tutkimus}

Juntusen mukaan Diakilla on ollut vahva rooli diakonian tutkimuskentällä erityisesti alan tutkimusta merkittävästi kehittäneiden voimahahmojen kaut- 
ta. Diakonian tutkimuksen pohjaa ja perustaa rakennettiin voimakkaasti vuosituhannen alussa, mutta viime vuosikymmenen muutokset, kuten korkeakoulujen rahoitusleikkaukset ovat Juntusen mukaan vaikuttaneet kielteisesti tutkimukseen käytettävissä oleviin resursseihin. Korkeakoulurahoituksen uuden rahoitusmallin mukanaan tuomat muutokset vaikeuttavat tilannetta edelleen.

Tutkimukselle on myös rakenteellisia esteitä, kuten tutkimustoiminnan huomioimisen haasteet työaikasuunnitelmissa. Juntunen tunnistaa haasteen. "Olemme pyrkineet siihen, että saataisiin opetus ja hanketoiminta vahvasti yhteen, ja hanketoiminnan kautta saadaan ajankohtaisinta tietoa opetuksen puolelle. Tämä ei ole kuitenkaan helppo järjestelmä. Sen eteen on tehtävä koko ajan systemaattista suunnittelutyötä.”

Juntusen mukaan diakonian tutkimuksen roolia Diakissa voitaisiin entisestään vahvistaa monitoimijaisen ja kansainvälisen yhteistyön keinoin. Diakonian tutkimuksen lähtökohtana on laaja-alaisuus ja monitieteisyys, ja hankkeissa ovat edustettuina esimerkiksi teologian, yhteiskuntatieteiden ja sosiaalitalouden alat sekä arviointi- ja vaikuttamisnäkökulmat. "Meillä tutkimus-, kehitys- ja innovaatiotoiminnassa käytetään monimenetelmällistä ja käytännönläheistä lähestymistapaa, pyritään tuomaan kehittävää tutkimusta osaksi meidän koulutusta ja pedagogiikkaa. Monialaisuus ja -tieteisyys on jatkuvasti mukana." Toisaalta laaja-alaisuus ei saa olla itsetarkoitus: "Hukkaako liiallinen laaja-alaisuus jotain diakonian syväymmärryksestä?”Juntunen kysyy.

Tutkimustoiminta vaatii jatkuvaa rahoituksen hakemista. Diakissa tutkimustoiminta painottuu käytännönläheisiin tutkimus- ja kehittämishankkeisiin. Juntusen mukaan tarvetta on isojen ja pitkäkestoisten hankkeiden hakemiseen, mutta pienemmilläkin hankkeilla on vaikuttavuutta. "Jos ajattelee alueita joilla toimimme, niin ajattelen että vaikuttavia kehittämistoimia on tehty pienemmillä hankkeilla. Ei se ole vaikuttavuudesta pois.”

\section{Diakoniakoulutuksen tulevaisuuden suuntaviivoja}

Suomessa on viime vuosina tehty fuusioita ja kumppanuussopimuksia yliopistojen ja ammattikorkeakoulujen välillä. Juntusen mukaan se on järkevää maakunnallisissa tapauksissa."Diak taas on valtakunnallinen. Me ei olla yhtä luontevasti löydetty kumppania tai tavoitteellisesti etsittykään, koska toimintalogiikkaamme ja alueellinen vaikuttaminen on erityyppistä kuin maakun- 
nallisilla korkeakouluilla.” Juntunen ennustaa, että tulevaisuudessa Diakin yhteistyö tulee varmasti tiivistymään niin ammattikorkeakoulujen kuin yliopistojen kanssa. Yhteistyötä tehdään jo tiiviisti esimerkiksi Arcadan, Humakin ja norjalaisen diakonia-alan VID:n korkeakoulun kanssa. ”Diakin pitää tarkastella ja arvioida kumppanit omasta strategiastaan käsin ja löytää luontevimmat, joiden kanssa voidaan jakaa yhteiset tavoitteet. Sisältö edellä, haetaan kumppanuutta niiden kautta."

Diakonian alan koulutuksen vetovoimaluvut ovat hyvät, mutta Juntusen mukaan tässä on vaihtelua alasta ja tarjonnasta riippuen. Esimerkiksi Diakin sairaanhoitajakoulutus on suosittua, kun taas kirkon nuorisotyön koulutuksen vetovoima on ollut viime vuosina vaatimattomampi. Tässäkin tutkimuksella on osansa. Juntusen mukaan vuonna 2020 tehty diakonisen hoitotyön oppikirja on ollut tärkeä alan itseymmärryksen jäsentäjä. Myös diakoninen sosiaalityö vaatisi ajankohtaista määrittelyä tästä ajasta käsin ja tulevaisuuteen suunnaten.

Diakissa on Juntusen mukaan mietitty aktiivisesti opiskelijoiden urapolkuja. Tutkimukseen liittyen yksi kysymys koskee diakonian alan tohtorikoulutusta. Olisi tärkeää löytää ja vahvistaa Diakin opiskelijoiden mahdollisia tohtoripolkuja. Juntusen mukaan ammattikorkeakouluja ja yliopistoja erotteleva duaalimalli on toistaiseksi pitänyt pintansa. Tulevaisuus on kuitenkin vielä avoin. Erityinen ongelmakohta on siirtyminen perustason ammattikorkeakoulututkinnoista maisteritutkintoihin ja ylemmistä ammattikorkeakoulututkinnoista tohtoriopintoihin. "Kysymys on paitsi järjestelmätasosta, myös henkisistä esteitä sille, miten ammattikorkeakoulututkinnon suorittanut pääsisi hyvällä tutkimussuunnitelmalla yliopistojen tohtoriohjelmiin mukaan. Miten saataisiin enemmän diakonia-alan tohtoreita?"

Henkistä kynnystä voitaisiin Juntusen mukaan purkaa selkeällä viestinnällä. "Ehkä pitää enemmän tuoda esiin sitä, mitä ylempi ammattikorkeakoulututkinto on. Voi olla, että on puhtaasti ennakkoluulojakin siitä, mitä koulutus tarkoittaa, mitä se sisältää, miten suoritettu, mitä se vastaa. Meidän pitää itse tehdä työtä ja nostaa myös tämän koulutuksen profiilia.”

Lisäksi Juntusen mielestä tarvitaan yhteistyötä korkeakoulujen välillä. Itä-Suomen yliopistossa virinnyt ajatus diakonian maisterintutkinnosta on Juntusen mukaan kiinnostava. Diak on jo tehnyt yhteistyötä Itä-Suomen yliopiston teologian osaston kanssa, ja tätä yhteistyötä voitaisiin entisestään vahvistaa. "Meidän pitää avoimesti ja kiinnostuneena suhtautua diakonia- 


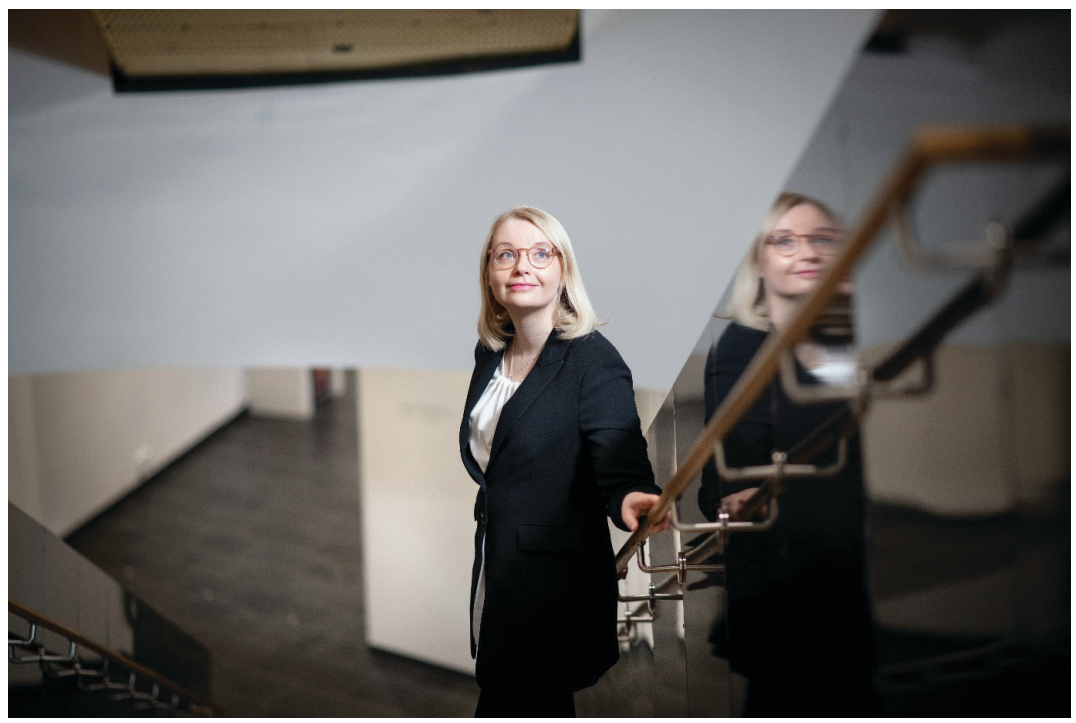

Kuva 2. Diakin rehtori Elina Juntunen pitää kiinnostavana ajatusta diakonian maisterintutkinnosta. Kuvaaja Meeri Utti.

maisteriavaukseen ja maisteriohjelmaan, mitä käsitykseni mukaan Itä-Suomen yliopistossa on pohdittu teologian osastolla.” Juntusen mukaan Diakin näkökulmasta keskeistä on pohtia sitä, mikä suhde maisterikoulutuksella olisi ylempään diakoniseen ammattikorkeakoulututkintoon ja mitä maisteritutkinto tarkoittaisi työelämän kannalta, alettaisiinko esimerkiksi tietyissä diakonia-alan tehtävissä edellyttää yliopistotutkintoa."Aina pitää miettiä myös minkälaisia vaikutuksia ja seurauksia näillä päätöksillä on", Juntunen tähdentää.

\section{Vuoropuhelua koulutuksen ja työelämän välillä}

Diakoniakoulutuksen tulevaisuuden suuntaviivat riippuvat paitsi korkeakoulusektorin, myös työelämän ja yhteiskunnan kehityssuunnista. Juntunen listaa monta suurta kysymystä: "Minkälainen on diakonityön tehtäväkuva tänään? Mitä se tulee olemaan? Minkälaisena asiantuntijatehtävänä se nähdään? Miten sitä kehitetään? Jos ajatellaan soteuudistuksen tai hyvinvoin- 
tialueiden näkökulmasta, mikä seurakuntien rooli on osana palvelujärjestelmää? Mitä tarkoittaa diakoniatyöntekijän työ siinä nyt ja tulevaisuudessa?”

Diakonian tutkimus -aikakauskirja tavoittaa paitsi alan tutkijoita, myös moninaisen joukon muita diakonia-alalla työskenteleviä ihmisiä. Terveisinä lukijoille Juntunen haluaa korostaa erityisesti Diakin ja työelämän kytköksiä. Kaikki työelämästä kumpuavat signaalit ja kehitysideat ovat Diakille tärkeitä. "Haluamme palvella työelämää. Vuorovaikutus Diakin ja työelämätahojen kanssa on äärimmäisen tärkeää ja sitä meidän pitää vaalia ja kehittää eri tavoin.” Yhtenä esimerkkinä Juntunen mainitsee opetukseen liittyvän työelämäyhteistyön. "On ollut tosi mielekäs malli, että meillä on ollut opetuksessa mukana erilaisissa tilanteissa työelämän edustajia. Säännöllinen, äärimmäisen tärkeä toimintamalli ja sitä opiskelijat arvostavat myöskin tosi paljon.” 